\title{
KONSERVASI ALAM: AKTIFITAS PAGUYUBAN MASYARAKAT PEDULI HUTAN (PMPH) DALAM BINGKAI LIVING QUR'AN DI KABUPATEN KUDUS
}

\author{
Salmah Fa'atin \\ Institut Agama Islam Negeri (IAIN) Kudus \\ salma@iainkudus.ac.id \\ Nailis Sa'adah \\ Institut Agama Islam Negeri (IAIN) Kudus \\ nailis.albasyar2@gmail.com
}

\begin{abstract}
Nature Conservation: Activities of the Paguyuban Masyarakat Peduli Hutan (PMPH) Society in the Living Qur'an Frame in Kudus Regency. This paper discusses the nature conservation activities carried out by the community of "Paguyuban Masyarakat Peduli Hutan (PMPH)" in Colo village, Dawe district, Kudus district. The focus of the study is to uncover PMPH activities in the living study of the Qur'an using the phenomenology paradigm. The study was conducted with a qualitative approach. Data collection is done by interview techniques, documentation, and observation. The results of the study found that the community of "Paguyuban Masyarakat Peduli Hutan (PMPH)" in Colo village, Dawe district, Kudus Regency had carried out activities / behaviors (living Qur'an) which actually constituted the values of the Koran concerning the duty of mankind to maintain and preserve the universe in order to bring benefits and prosperity to the people. The concept of ihsan, taskhir and ta'mir has manifested itself in the action of PMPH. Manifestation of social and individual piety, worship and charity charity created in PMPH slogan "Forest is trustworthy, Keeping it is worship"

Tulisan ini membahas tentang aktifitas konservasi alam yang dilakukan oleh komunitas Paguyuban Masyarakat Peduli Hutan (PMPH) di desa Colo kecamatan Dawe kabupaten Kudus. Fokus kajiannya adalah mengungkap aktifitas PMPH dalam kajian living Qur'an dengan menggunakan paradigma fenomenologi. Penelitian dilakukan dengan pendekatan kualitatif. Pengumpulan data dilakukan dengan teknik
\end{abstract}


wawancara, dokumentasi, dan observasi. Hasil penelitian menemukan bahwa komunitas Paguyuban Masyarakat Peduli Hutan (PMPH) di desa Colo kecamatan Dawe Kabupaten Kudus telah melakukan aktifitasaktifitas/perilaku-perilaku (living Qur'an) yang sejatinya merupakan nilainilai al-Qur'an tentang tugas manusia untuk menjaga dan melestarikan alam semesta agar dapat membawa manfaat dan kemaslahahatan umat. Konsep ihsan, taskbir dan ta'mir telah mewujud dalam aksi PMPH. Manifestasi kesalehan sosial dan individu, ibadah dan amal jariyah tercipta dalam slogan PMPH "Hutan adalah amanah, Menjaganya adalah Ibadah".

Keywords: kesadaran ekologi, komunitas peduli hutan, konservasi alam, living Qur'an

\section{Pendahuluan}

Beragam bencana alam akhir-akhir ini kerap menjadi pemberitaan utama di berbagai media Indonesia, baik cetak, elektronik maupun sosial. Sepanjang tahun 2018 lebih dari lima bencana alam besar menimpa Indonesia. Sejumlah gempa bumi,tsunami, letusan gunung api, hingga fenomena likuifaksi menelan banyak korban. Indonesia yang terletak di kawasan Cincin Api Pasifik memang memiliki potensi bencana alam yang tinggi.

Kabupaten Kudus merupakan salah satu daerah di Provinsi Jawa Tengah yang masuk wilayah rawan bencana alam, terutama bencana alam banjir dan tanah longsor. Topografi kabupaten Kudus merupakan daerah yang rawan bencana baik itu bencana banjir maupun tanah longsor. Dari sembilan kecamatan yang ada di Kudus, terdapat dua kecamatan yakni Gebog dan Dawe yang merupakan kawasan rawan bencana tanah longsor. Enam kecamatan lain kategori rawan bencana banjir ${ }^{1}$. Bencana banjir kerap mengintai sejumlah wilayah di Kudus saat turun musim hujan. Bahkan, Pemerintah kabupaten Kudus berencana membentuk badan bernama Emergency Center di bawah kendali Badan Penanggulangan Bencana Daerah (BPBD) Kudus. Emergency Center nantinya akan bertugas khusus dalam

\footnotetext{
${ }^{1}$ Dede Rodin, "Al Quran Dan Konservasi Lingkungan: Telaah Ayat-Ayat Ekologis," Al-Tabrir 17, no. 2 (2017): 407, http://jurnal.iainponorogo.ac.id/index.php/tahrir/article/view/1035.
} 
penanganan bencana secara cepat di masing-masing wilayah kecamatan $^{2}$.

Kesadaran ekologi begitu penting bagi masyarakat Kudus, apalagi kondisi alam terus mengalami degradasi dan kian memprihatinkan. Kerusakan hutan ini tak bisa dibiarkan begitu saja. Membangun kesadaran ekologi menjadi sesuatu yang sangat urgen. Hal ini dapat diimbangi dengan proses internalisasi kesadaran ekosistem secara alami ${ }^{3}$. Masyarakat desa Colo sudah melakukan prinsip-prinsip etika lingkungan hidup, berupa norma peran untuk menjaga kawasan hutan Muria. Strategi masyarakat desa Colo dalam melindungi Kawasan Hutan Muria, membentuk organisasi lokal yang peduli terhadap lingkungan yaitu PMPH (Paguyuban Masyarakat Pelindung Hutan).

Konservasi alam yang dilakukan masyarakat desa Colo di kawasan Muria dapat dimaknai sebagai respon terhadap nilai-nilai ajaran al-Qur'an tentang anjuran dan perintah untuk tidak berbuat kerusakan di bumi. Perilaku masyarakat yang diperoleh dari teksteks al-Qur'an dapat dikategorikan sebagai living Qur'an ${ }^{5}$. Tulisan ini akan mengungkap every day life Paguyuban Masyarakat Peduli Hutan (PMPH) di desa Colo Kabupaten Kudus dengan kajian living Qur'an. Pertama, bagaimana fenomena kehidupan masyarakat dalam komunitas PMPH terkait dengan upaya konservasi

2 Abdul Mustaqim, "Metode Penelitian Living Qur'an Model Penelitian Kualitatif," in Metodologi Penelitian Living Qur'an Dan Hadis, 1st ed. (Yogyakarta: Teras, 2007), 71.

3 "Kategori Daerah Rawan Bencana, Pemkab Dan Polres Kudus Gelar Apel Siaga Bencana," Kategori daerah rawan bencana, pemkab dan Polres Kudus gelar apel siaga bencana, 2018, https://elshinta.com/news/128958/0000/00/00/kategori-daerah-rawan-

bencana-pemkab-dan-polres-kudus-gelar-apel-siaga-bencana.

4 "Waspada Bencana Banjir, Pemkab Kudus Bentuk Emergency Center Di Bawah BPBD - Tribun Jateng," 2018, http://jateng.tribunnews.com/2018/11/16/waspada-bencana-banjir-pemkabkudus-bentuk-emergency-center-di-bawah-bpbd.

${ }^{5}$ Wasino \& Dewi Lisnoor Setyowati Wibowo, Hendro Ari, "Kearifan Lokal Dalam Menjaga Lingkungan Hidup (Studi Kasus Masyarakat Di Desa Colo Kecamatan Dawe Kabupaten Kudus)," Journal of Educational Social Studies 1, no. 1 (2012):

https://journal.unnes.ac.id/sju/index.php/jess/article/view/79/71.

TAJDID Vol. 17, No. 1, Januari- - Juni 2018 | 53 
lingkungan. Kedua, apa makna aktifitas yang dilakukan oleh komunitas masyarakat PMPH dalam konteks kajian living Qur'an.

Penelitian tentang komunitas PMPH masyarakat desa Colo telah dilakukan. Pertama, kajian tentang kearifan lokal masyarakat dalam menjaga lingkungan hidup dilakukan oleh Hendro Ari wibowo, Wasino \& Dewi Lisnoor Setyawati ${ }^{6}$. Tulisan ini menggali informasi tentang peranan kearifan lokal pada lingkungan dan keterkaitan kearifan lokal dengan prinsip etika lingkungan hidup di Kawasan Gunung Muria Desa Colo Kabupaten Kudus. Kedua, kajian tentang bagaimana peran masyarakat desa Colo dalam upaya konservasi alam ${ }^{7}$. Artikel ini bertujuan untuk mengetahui peran masyarakat desa Colo dalam upaya konservasi sumber daya hayati. Ketiga, pembahasan tentang wilayah di sekitar Makam Sunan Muria, motif kedatangan para peziarah di Makam Sunan Muria, prosesi seremonial ziarah di Makam Sunan Muria dan dampak wisata religi makam Sunan Muria terhadap kehidupan sosial dan ekonomi masyarakat Desa Colo Kecamatan Dawe Kabupaten Kudus.

Dengan demikian, penelitian terhadap komunitas PMPH masyarakat desa Colo kecamatan Dawe dalam kajian living Qur'an belum dilakukan. Kendati tentunya penelitian-penelitian yang telah ada tersebut sangat memberikan kontribusi data yang bermanfaat untuk tulisan ini.

Fenomena living Qur'an merupakan fenomena sosial, sehingga model metode penelitian yang digunakan adalah model penelitian sosial. Dalam tulisan ini, kajian living Qur'an menggunakan metode penelitian kualitatif, karena dalam penelitian living Qur'an metode yang paling tepat adalah kualitatif ${ }^{8}$. Unsur-unsur metode penelitian yang dipaparkan dalam tulisan ini adalah lokasi, pendekatan dan

${ }^{6}$ Wibowo, Hendro Ari, 26.

7 Moh Muhtador, "Pemaknaan Ayat Al-Quran Dalam Mujahadah: Studi Living Qur' an Di PP Al-Munawwir Krapyak Komplek Al- Kandiyas," Jurnal $\begin{array}{lllll}\text { Penelitian } & \text { 8, no. } & 1 & \text { (2014): } & \text { 97, }\end{array}$ journal.stainkudus.ac.id/index.php/jurnalPenelitian/article/download/1343/11 87.

${ }^{8}$ Wibowo, Hendro Ari, "Kearifan Lokal Dalam Menjaga Lingkungan Hidup (Studi Kasus Masyarakat Di Desa Colo Kecamatan Dawe Kabupaten Kudus).”

54 | TAJDID Vol. 17, No. 1, Januari - Juni 2018 
prespektif, teknik pengumpulan data, unit analisis data, strategi pengumpulan data dan penyajian data?

Lokasi penelitian ini adalah di hutan Muria yang berada di sekitar kawasan pegunungan Muria Desa Colo Kecamatan Dawe Kabupaten Kudus, khususnya Komunitas PMPH (Paguyupan Masyarakat Pelindung Hutan) yang didirikan untuk melestarikan alam dan lingkungan hidup. Penelitian ini dilakukan pada tahun 2018, tepatnya pada bulan September-November 2018.

Informasi tentang aktifitas komunitas masyarakat $\mathrm{PMPH}$ digali dengan teknik wawancara mendalam (depth interview) yang direkam dan diprocedingkan. Selain itu juga digunakan teknik observasi terhadap tindakan masyarakat komunitas PMPH.

Sumber data primer penelitian meliputi komunitas PMPH (Paguyupan Masyarakat Pelindung Hutan), kelompok tani, tokoh masyarakat desa, dan sebagian masyarakat desa. Data sekunder diperoleh dari berbagai sumber, seperti buku-buku, tafsir yang ada relevansinya dengan judul, artikel, majalah, jurnal, internet, maupun media lain yang mendukung dalam penelitian. Dalam hal ini meliputi literatur-literatur yang berhubungan dengan obyek penelitian. Di samping itu data juga diperoleh dari dokumendokumen yang ada di Desa Colo Kecamatan Dawe Kabupaten Kudus.

Reduksi data oleh peneliti yaitu merangkum memilih dan memisahkan data hasil observasi, wawancara, ataupun dokumentasi yang tidak berkaitan dengan penelitian. Penulis mereduksi data yang berkenaan dengan upaya pelestarian lingkungan hidup komunitas PMPH dan masyarakat Desa Colo Kecamatan Dawe Kabupaten Kudus. Selanjutnya, penyajiaan data yaitu memilih data yang sesuai dengan fokus penelitian dan bisa digunakan untuk melengkapi jawaban dari rumusan masalah yang telah ditetapkan sebelumnya oleh penulis. Dilanjutkan dengan pengumpulan data yang terpilih disusun secara sistematis dalam penyajiannya baik dalam bentuk narasi, diagram, atau tabel agar

\footnotetext{
${ }^{9}$ Kistantia Elok Mumpuni, Herawati Susilo, and Fatchur Rohman, "Peran Masyarakat Dalam Upaya Konservasi The Role of Society Toward Concervation," in Seminar Nasional XII Pendidikan Biologi FKIP UNS 2015 (LIPI, 2015), 779-82, http://jmb.lipi.go.id/index.php/jmb/article/view/344/294.
} 
bisa dilakukan penarikan kesimpulan oleh penulis dan diakhiri dengan pengecekan ulang agar mudah dianalisis kemudian baru diverifikasi data dengan bantuan informan.

\section{Mengenal Komunitas Paguyuban Masyarakat Peduli Hutan (PMPH) di Kabupaten Kudus}

Desa Colo merupakan salah satu bagian dari wilayah Kecamatan Dawe Kabupaten Kudus yang terletak di sebelah utara dari kota Kudus dengan jarak18 km. Desa Colo dikelilingi oleh area hutan lindung, masyarakat biasanya menyebut dengan alas. Selain itu Desa Colo juga terkenal dengan obyek pariwisatanya yaitu area ziarah makam waliyullah Sunan Muria (Walisongo). Desa Colo sebagai basis berdirinya Komunitas PMPH terletak di lereng gunung Muria. Nama Colo tidak terlepas dari sejarah kehidupan Sunan Muria ketika dahulu berdakwah dan menyebarkan Islam ${ }^{10}$. Masyarakat biasa menyebut nama Colo dengan dua versi. Pertama, Han Colo, Han yang berarti gunung, sedangkan Colo adalah Colo "Gunung yang berada di Colo ini". Kedua, Cecolo. Semua versi itu dianggap benar. ${ }^{11}$ Asal-usul Desa Colo lebih tepatnya memang banyak yang tidak mengetahui, mungkin hanya dari cerita rakyat yang santer terdengar secara turun-temurun dari nenek moyang. Desa Colo tidak bisa dilepaskan sejarahnya dari Sunan Muria dan keturunan beliau yang berjulukan Panembahan Ageng Colo dan Pangeran Pandak (wali yang menyebarkan Islam di Dukuh Pandak).

Adanya Makam Sunan Muria, dipercaya masyarakat Desa Colo dan sekitarnya membawa keberkahan sendiri bagi urusan mencari rizki. Tak ayal jika mata pencaharian masyarakat Desa Colo adalah sebagai pedagang, dan jasa ojek dari pangkalan bus peziarah sampai makam Sunan Muria di atas. Selain itu di Pegunungan Muria terdapat Hutan Lindung atau alas yang luas keseluruhannya mencapai $69.812,08$ ha, dan terbagi menjadi tiga

\footnotetext{
${ }^{10}$ Bambang Sugiarno, Tokoh Desa Colo, Wawancara di Desa Colo, Tanggal 19 November 2018.

${ }^{11}$ Bambang Sugiarno, Tokoh Desa Colo, Wawancara di Desa Colo, Tanggal 19 November 2018.
}

56 | TAJDID Vol. 17, No. 1, Januari - Juni 2018 
kabupaten $^{12}$, yakni Kabupaten Jepara, Kabupaten Pati dan Kabupaten Kudus 2.377,57 ha menandakan bahwa sebagian besar masyarakat Colo juga berprofesi sebagai petani, dari mulai petani tanaman jamu (apotik hidup), petani kopi, dan petani parijoto.

Berkaitan dengan hutan Muria, masyarakat Desa Colo memiliki bentuk kesadaran cukup tinggi untuk menjaga kelestarian hutan. Hal ini terbukti dengan adanya kelompok lokal yang secara swadaya berupaya untuk menjaga dan melestarikan hutan lindung Muria, yakni komunitas atau kelompok PMPH (Paguyuban Masyarakat Pelindung Hutan Muria), dan Kelompok Tani Kuncen Rejo yang baru diresmikan oleh Bapak Bupati Tamzil tahun $2018 .^{13}$

Latar belakang awal munculnya komunitas PMPH adalah dari naluri turun temurun Sunan Muria sekitar 490 tahun yang lalu. Sunan Muria sudah mensyiarkan Islam di tengah hutan belantara.Warga Colo selaku anak cucu dari Sunan Muria merasa sudah seharusnya berperan aktif untuk melestarikan hutan, menjaga dan merawat hutan di kawasan Gunung Muria. ${ }^{14}$

Pasca reformasi pada tahun 1998, berimbas pada lahan-lahan hutan banyak yang berubah fungsi menjadi lahan pertanian. Hal ini dikarenakan aktivitas masyarakat yang semakin tinggi, sehingga menyebabkan fungsi hutan lindung menjadi terbaikan. Banyak pohon-pohon besar ditebangi dan diganti dengan tanaman kopi. ${ }^{15}$ Selain pembalakan liar (illegallogging), hutan Muria (Kudus Utara) rusak akibat beberapa hal. Pertama, adanya hama semut bungkuk di kebun kopi yang bisa mematikan dan menghancurkan tanaman. Kedua, mulai tumbuhnya industri pariwisata di Muria, sehingga

12 Mochamad Widjatnarko, PsikologiLingkungan (Kudus: Badan Penerbit Universitas Muria Kudus, 2014), 54.

13 Joni Awang Ristihadi, Kepala Desa Colo, Wawancara di Desa Colo, Tanggal 15 November 2018.

14 Shokib Garno Sunarno, Ketua PMPH dan Juru Kunci Makam Sunan Muria, wawancara di Desa Colo, Tanggal 20 Oktober 2018.

15 Pranyoto Shofil Fu'ad, Sekretaris Komunitas PMPH, Wawancara di Desa Colo, Tanggal 19 Oktober 2018.

TAJDID Vol. 17, No. 1, Januari - Juni 2018 | 57 
lebih memilih usaha perdagangan dan jasa ojek angkutan umum yang berakibat terbengkalainya hutan. ${ }^{16}$

Masyarakat menyoroti banyaknya aktivitas pembalakan liar (illegal logging) secara besar-besaran di beberapa tempat khususnya di kawasan Hutan Muria. Muncul kekhawatiran melihat sebagian hutan lindung di luar kendali dan sudah beralih fungsi. Beberapa tokoh desa yang diprakasai oleh Bapak Shokib Garno Sunarno dan kepala desa Bapak H. Abdul Haris, membentuk sebuah organisasi kelompok dengan swadaya pelindung hutan yang sekarang dikenal dengan nama PMPH (Paguyuban Masyarakat Pelindung Hutan Muria). Pertama kali anggotanya hanya 9 orang, bertambah lagi menjadi 15 orang dan sekarang sudah menjadi 39 orang.

Komunitas PMPH mempunyai slogan "Hutan adalah amanah, Menjaganya adalab ibadab" sebagai motivasi dan penyemangat para anggotanya yang terdiri dari warga Desa Colo. Mereka beranggapan bahwa sebagai warga Colo yang hidup dari kecil di Colo, hutan telah ada lebih dulu dan sudah seperti itu. Semua masyarakat Colo dan sekitarnya mencari nafkah di Colo, artinya mereka merasa mempunyai tanggung jawab moral untuk merawat hutan dan lingkungan sekitar.

Ruang lingkup aktifitas PMPH adalah menjaga semua hutan kawasan Muria di tiga kota, yakni Kudus, Jepara dan Pati. Tugas PMPH adalah menjaga hutan lindung dari kerusakaan dan pembalakan liar (illegal logging), serta menjaga keanekaragaman hayati di dalamnya. Bagi PMPH dan masyarakat Colo, hutan yang sudah terlanjur menjadi kebun kopi harus dirawat semaksimal mungkin. Jika ditanami kopi, maka kopinya harus dirawat agar subur dan kebunnya kembali hijau.

Komunitas PMPH tidak memiliki tendensi finansial. Mereka hanya tulus berniat lillahita'ala ingin merawat hutan agar terhindar dari bencana-bencana yang bisa mengancam kapan saja ${ }^{17}$.

\footnotetext{
${ }^{16}$ Mastur bin Mardi, Tokoh Desa Colo, Wawancara di Desa Colo, Tanggal 28 Oktober 2018.

${ }_{17}$ Pranyoto Shofil Fu'ad, Sekretaris Komunitas PMPH, Wawancara di Desa Colo, Tanggal 19 Oktober 2018.
}

58 | TAJDID Vol. 17, No. 1, Januari - Juni 2018 


\section{Konservasi Alam dalam Bingkai Living Qur'an Sekilas tentang Kajian Living Qur'an}

The Living al-Qur'an atau "al-Qur'an yang hidup" secara antropologis pada dasarnya adalah memandang fenomena ini sebagai fenomena sosial-budaya, yakni sebagai sebuah gejala yang berupa pola-pola perilaku individu-individu yang muncul dari dasar pemahaman mereka mengenai al-Qur'an. Dengan perspektif ini fenomena yang kemudian menjadi objek kajian bukan lagi alQur'an sebagai kitab, tetapi perlakuan manusia terhadap al-Qur'an dan bagaimana pola-pola perilaku yang dianggap berdasarkan atas pemahaman tentang al-Qur'an itu diwujudkan. Objek kajian di sini adalah bagaimana berbagai pemaknaan terhadap al-Qur'an di atas hadir, dipraktekkan dan berlangsung dalam kehidupan sehari-hari manusia $^{18}$.

Al-Qur'an yang hidup di tengah kehidupan sehari-hari manusia bisa mewujud dalam bentuk yang beraneka-ragam, yang bagi sebagian pemeluk Islam mungkin malah telah dianggap menyimpang dari ajaran-ajaran dasar dalam agama Islam itu sendiri. Kajian living al-Qur'an di sini kemudian memang lebih dekat dengan kajian-kajian ilmu sosial-budaya seperti antropologi dan sosiologi, di mana peneliti tidak lagi mempersoalkan kebenaran sebuah tafsir atau perlakuan terhadap al-Qur'an, karena tujuan penelitian bukanlah 'mengadili' atau 'menilai' sebuah pemaknaan dan pengejawantahannya dalam kehidupan, tetapi memahami, memaparkan dan menjelaskan gejala-gejala tersebut sebaik-baiknya.

Fenomena living al-Qur'an juga dapat dikatakan sebagai "qur'anisasi" kehidupan, yang artinya memasukkan al-Qur'an sebagaimana al-Qur'an tersebut dipahami ke dalam semua aspek kehidupan manusia, atau menjadikan kehidupan manusia sebagai suatu arena untuk mewujudnya al-Qur'an di bumi.

Menempatkan pemaknaan al-Qur'an dan perwujudannya dalam kehidupan sehari-hari manusia sebagai titik pusat kajian,

18 Abdul Mustaqim, "Metode Penelitian Living Qur'an Model Penelitian Kualitatif," in Metodologi Penelitian Living Qur'an Dan Hadis, 1st ed. (Yogyakarta: Teras, 2007), 71. 
maka paradigma-paradigma yang diperlukan tidak lagi sama dengan paradigma yang digunakan untuk mengkaji al-Qur'an sebagai sebuah kitab. Terdapat beberapa paradigma antropologi yang dianggap layak digunakan untuk mempelajari living al-Qur'an. Dari sekian banyak paradigma tersebut, paradigma yang dipandang dapat dipakai dan dapat memberikan hasil yang memuaskan jika diterapkan dengan baik adalah paradigma akulturasi, paradigma, struktural, paradigma fungsional, paradigma fenomenologi dan paradigma hermeneutika ${ }^{19}$.

Tulisan ini akan mengkaji aktifitas komunitas PMPH dalam bingkai living Qur'an dengan menggunakan paradigma fenomenologi. Penulis akan berusaha mengungkap kesadaran atau pengetahuan pelaku mengenai 'dunia' tempat mereka berada, kesadaran mereka mengenai perilaku-perilaku mereka sendiri. Hal ini dipandang sangat penting karena pemahaman atau pengetahuan mengenai 'dunia' inilah yang dianggap sebagai dasar bagi pewujudan pola-pola perilaku manusia dalam kehidupan seharihari. Dengan memahami 'pandangan dunia' atau 'pandangan hidup' ini penulis kemudian akan dapat 'mengerti' mengapa polapola perilaku tertentu diwujudkan, dan bukan perilaku-perilaku yang lain.

Dengan perspektif fenomenologis ini penulis tidak lagi menilai kebenaran atau kesalahan pemahaman para pelaku tertentu mengenai al-Qur'an, karena yang dianggap penting bukan lagi benar salahnya sebuah tafsir atau pemahaman, tetapi isi tafsir itu sendiri. Isi tafsir inilah yang menjadi dasar dari pola-pola perilaku tertentu ${ }^{20}$.

\section{Konservasi Alam Komunitas PMPH: Persepsi dan Aksi}

Allah menciptakan makhluk-Nya itu satu paket, karena inilah kuasa Allah Ta'ala. Manusia diciptakan Allah dan ditaruhlah di bumi untuk hidup dan berkehidupan.Di bumi ada gunung, laut, ada darat, pulau, ada siang-malam, ada kebun, sawah, hutan dan

${ }^{19}$ Heddy Shri Ahimsa Putra, “The Living Al-Qur'an: Beberapa Perspektif Antropologi," Jurnal Penelitian Sosial Keagamaan 20, no. 1 (2012): 250, http://www.journal.walisongo.ac.id/index.php/walisongo/article/view/198/1 79.

${ }^{20}$ Putra, 254-57.

60 | TAJDID vol. 17, No. 1, Januari - Juni 2018 
dicukupkan kehidupannya di bumi dengan seluruh isinya. Manusia berkewajiban, untuk bekerja dan bergerak di bumi, karena adanya aktivitas manusia di bumi untuk menjaga dan merawat atas apa yang telah diberikan Tuhan. Sudah seharusnya manusia hidup di bumi menjaga keselarasan dan keseimbangan ekosistem yang ada di bumi ${ }^{21}$.

Jadi tergantung bagaimana kita memaknai dari tempat tinggal kita. Apabila manusia tinggal di suatu desa yang di kelilingi oleh tanah persawahan, maka sudah seharusnya melestarikan alam atau lingkungan itu adalah merawat apa yang ada di sekitarnya itu supaya bisa menghasilkan produksi untuk keberlangsungan hidup manusia itu sendiri. Begitu pula bagi manusia yang tinggal di daerah pegunungan yang disekelilingnya terdapat hutan rimba atau hutan lindung dan perkebunan, melestarikan alam bisa diartikan jangan merusak alam hutan yang telah asri.Justeru dengan merawatnya agar bisa menghasilkan produksi untuk keberlangsungan kehidupan manusia.

Dalam tataran pemikiran masyarakat dan anggota komunitas PMPH Desa Colo, dalam memaparkan definisi melestarikan lingkungan hidup atau hutan tidak jauh berbeda.Karena dalam komunitas PMPH sendiri bepedoman "Hutan adalah Amanah, Menjaganya dan Merawatnya adalab Ibadah,"itu adalah slogan yang dipegang teguh dan diyakini para anggotanya. Dari slogan tersebut, para anggota PMPH secara swadaya tanpa tendensi apa-apa, lillahi ta'ala ingin menjaga dan merawat hutan lindung yang ada di Pegunungan Muria. Makna "melestarikan alam" banyak diidentikkan dengan slogan PMPH.

Seperti halnya persepsi Ketua PMPH, Bapak Shokib Garno Sunarno, pada tahun 2016 telah mendapatkan penghargaan Kalpataru dari Bapak Presiden Ir. H. Joko Widodo, beliau merasa merinding dan terdiam sesaat ketika menjelaskan makna dari melestarikan lingkungan atau alam. Beliau menjelaskan dengan menyelaraskan pada slogan PMPH. Siapa orang yang menjaga dan melestarikan apa yang telah diamanahkan oleh Allah, pasti akan menambah amal ibadah.Kebanyakan manusia beramalhanya

${ }^{21}$ Mastur bin Mardi, Tokoh Desa Colo, Wawancara di Desa Colo, Tanggal 28 Oktober 2018.

TAJDID Vol. 17, No. 1, Januari - Juni 2018 | 61 
sesama manusia saja, padahal kita tahu beramal bisa dengan siapa saja termasuk dengan lingkungan alam di sekitar kita. Mereka percaya bahwa alam bisa berdzikir dan diajak dzikir, karena bagi mereka hutan adalah segala-galanya ${ }^{22}$.

Pengertian melestarikan lingkungan hidup atau melestarikan hutan diungkapkan oleh Bapak Teguh Budi Wiyono selaku bendahara komunitas PMPH, bahwa arti dari melestarikan itu adalah menjaga dan mengembalikan fungsinya kembali dari hutan maupun lingkungan itu sendiri.Apabila membayangkan hutan Muria gundul dan tidak dihijaukan kembali pasti satu dua tahun ke depannya sudah habis. Sedangkan generasi penerus akan merasakan kehancurannya. Menjaga dan mengembalikan fungsinya dari mulai resapan air yang semula hilang dikembalikan menjadi resapan air. Hutan dihijaukan kembali, apabila hutan dihijaukan kembali sumber mata air sudah pasti melimpah ${ }^{23}$.

Melestarikan lingkungan hidup atau alam itu bukan hanya sekedar menanam saja, akan tetapi merawat dan menjaganya, agar fungsi hutan itu tetap pada fungsi hutan yang sesungguhnya. Baik dari fungsi lindung itu sendiri, kelestarian satwanya, dan kelestarian ekosistem yang ada di dalamnya.Jadi melestarikanmempunyai arti yang lebih luas. Selain menjaga hutan, PMPH juga melakukan kegiatan untuk kelestarian satwa.Kita bekerjasama dengan PKSDA dan Djarum Foundation. ${ }^{24}$

Para anggota kelompok PMPH memahami QS. Al-Baqarah ayat 30, dengan berpedoman pada slogan yang dipercayainya, yakni"Hutan adalah amanah, merawatnya adalab ibadah. Apabila memperlakukan hutan yang di dalamnya ada tanaman dan pepohonan, dan juga hewan itu sama dengan memperlakukan manusia. Karena sebenarnya, tumbuhan dan hewan itu selalu bertasbih kepada Allah dan semesta. Jadi, tumbuh-tumbahan, pohon-pepohonan dan hewan itu tidak sekedar tumbuhan dan

22 Shokib Garno Sunarno, Ketua PMPH dan Juru Kunci Makam Sunan Muria, Wawancara di Desa Colo, Tanggal 20 Oktober 2018.

23 Teguh Budi Wiyono, Bendahara Komunitas PMPH, Wawancara di Desa Colo, Tanggal 21 Oktober 2018.

24 Pranyoto Shofil Fu'ad, Sekretaris Komunitas PMPH, wawancara di Desa Colo, Tanggal 19 Oktober 2018.

62 | TAJDID vol. 17, No. 1, Januari - Juni 2018 
hewan saja, dan apabila kita sudah berbuat baik dan kebaikan apa yang kita perbuat terhadap hutan suatu saat hutan akan memberikan kebaikan kepada kita. Karena hutan ini adalah amanah untuk kita, hidup berdampingan dengan hutan. Menjaganya sudah menjadi kewajiban dan merupakan ibadah. Apabila manusia melalaikannya, alam dan lingkungan pasti akan murka ${ }^{25}$.

Ayat tentang manusia sebagai khalifah di bumi dimaknai dengan pepatah"barang siapa yang menanam, pasti akan menuai". Berita/peristiwa yang terjadi sekarang ini, mulai adanya banjir bandang, tanah longsor, banjir lumpur itu disebabkan karena ulah tangan perbuatan manusia yang tidak bertanggung jawab."26 Apabila setiap individu dari kita mengetahui dan mengimplementasikannya, kita memang menjadi khalifah di bumi yang sudah seharusnya untuk menjaga dan tidak merusak, diyakin bencana itu tidak akan ada." ${ }^{27}$

Manusia itu memang harus hidup dengan selaras. Kita harus menyadari, misalnya kalau orang Muslim hendak melakukan ibadah, seharusnya dimulai dengan wudlu, kita bisa membayangkan bagaimana kalau air itu tidak ada. Bagaimana caranya air agar tetap ada, kita harus menjaga supaya air itu ada terus, dengan menjaga sumber-sumber air itu, dengan adanya menjaga keselarasan itu.Adanya sedekah bumi di setiap daerah khususnya Desa Colo merupakan bentuk rasa syukur kepada Allah yang telah memberikan kita sumber kehidupan ${ }^{28}$.

Adanya gerakan lingkungan yang berhubungan dengan kearifan lokal yang dihubungkan dengan kepercayaan masyarakat setempat akan adanya kekuatan di luar manusia yang turut menjaga kelestarian hutan. Aura spiritual juga terlihat adanya

${ }^{25}$ Ibid.

${ }^{26}$ Teguh Budi Wiyono, Bendahara Komunitas PMPH, Wawancara di Desa Colo, Tanggal 21 Oktober 2018.

${ }^{27}$ Fridy Kiswantoro, Perangkat Desa KAUR Umum dan Anggota Pemuda Komunitas PMPH, wawancara di Dukuh Kombang Desa Colo, Tanggal 26 Oktober 2018.

${ }^{28}$ Mochamad Widjanarko, Penulis Buku Psikologi Lingkungan Berbasis Kearifan Lokal dan Dosen Universitas Muria Kudus, Wawancara di Kampus Universitas Muria Kudus (UMK), Tanggal 16 November 2018.

TAJDID Vol. 17, No. 1, Januari - Juni 2018 | 63 
makam Sunan Muria yang berada di Desa Colo, kawasan hutan Muria bagian timur telah memberikan kontribusi secara real akan adanya tindakan menjaga keutuhan hutan Desa Colo.

Adanya pengaruh besar dari Sunan Muria, misalnya orang akan berpikir kalau akan merusak alam karena di situ ada makam Sunan Muria, jelas ada hubungannya dengan makam Sunan Muria. Jadi Sunan Muria itu menjadi salah satu komponen penting dalam hal kondisi lingkungan yang bagus di Muria juga." 29

Untuk mempertahankan dan menyelamatkan lingkungan banyak upaya yang ditempuh oleh manusia. Namun yang paling penting di sini adalah berawal dari perbaikan perilaku manusia terhadap lingkungan. Dan biasa disebut dengan etika dalam lingkungan. Etika bersumber pada kesadaran dan moral seseorang. Etika lingkungan pada dasarnya adalah perbuatan apa yang dinilai baik untuk lingkungan dan apa yang tidak baik bagi lingkungan ${ }^{30}$. Etika lingkungan hidup bisa diwujudkan dalam kehidupan kita sehari-hari.

Etika manusia terhadap lingkunganya yaitu manusia harus bisa bersatu dengan alam. Manusia harus bisa merawat dan mengfungsikan alam sebagaimana mestinya. Saat ini hutan dirambah untuk dijadikan perkebunan, bahkan ada yang air dari sumber airnya dijual. Sejatinya perlu dicermati filosofi orang tua bahwa alam itu seharusnya digunakan oleh manusia seperlunya saja, tidak untuk dimanfaatkan sebesar-besarnya. Jika alam digunakan seperlunya, keturunan dan anak cucu pasti juga bisa menikmatinya di kemudian hari. Namun jika alam terus menerus dieksploitasi, tinggal menunggu waktu saja."31

Alam juga layak dihormati (respect). Menghormati lingkungan atau alam dilakukan dengan tidak berbuat kerusakan-kerusakan

${ }^{29}$ Mochamad Widjanarko, Penulis Buku Psikologi Lingkungan Berbasis Kearifan Lokal dan Dosen Universitas Muria Kudus, Wawancara di Kampus Universitas Muria Kudus (UMK), Tanggal 16 November 2018.

30 Khafidhoh, "Teologi Bencana Dalam Perspektif M. Quraish Shihab," ESENSIA 14, no. 1 (2013): 56, http://ejournal.uinsuka.ac.id/ushuluddin/esensia/article/view/141-03/693.

31 Teguh Budi Wiyono, Bendahara Komunitas PMPH, Wawancara di Desa Colo, Tanggal 21 Oktober 2018.

64 | TAJDID Vol. 17, No. 1, Januari - Juni 2018 
terhadap alam, misalya dengan mengurangi penggunaan kertas, karena kertas terbuat dari tumbuhan."32

\section{Konservasi Alam: Aktifitas Komunitas PMPH dalam Bingkai Living Qur'an}

Beragam upaya dilakukan oleh kelompok PMPH dalam melestarikan hutan Pegunungan Muria. Pertama, Mengajak masyarakat untuk sadar akan lingkungan butan. Komunitas PMPH mengupayakan bagaimana agar masyarakat bisa sadar akan lingkungan yang ada di sekitarnya. Terkadang dengan cara memberikan materi dalam khotbah Jum'at ketika shalat Jum'at berlangsung di masjid-masjid. Atau misalnya ketika ada kegiatan pengajian, dan Bapak Shokib atau Bapak Shofil jadi pembicara itu pasti disisipkan materi tentang hutan dan melestarikan hutan, dan itu cara yang paling efektif. Dengan cara itu, masyarakat telah mendapatkan edukasi tentang pentingnya menjaga kelestarian alam. $^{33}$.

Kedua, Menganjurkan untuk tidak membuang sampab di butan. Apabila seseorang mengajak orang lain berbicara mengenai pelestarian alam atau lingkungan, maka dari hal kecil harus menerapkan dalam diri sendiri, misalnya dengan mengharuskan membuang sampah pada tempatnya, maka harus bisa mengurangi produksi sampah plastik. Harus konsistensi antara yang dikampanyekan, dirisetkan, dan apa yang dilakukan."34 Masyarakat Desa Colo memiliki kesadaran akan pentingnya membuang sampah pada tempatnya. Masyarakat pun saat ini telah menyambut baik kebijakan pemerintah desa terkait pengadaan pembuangan sampah sementara. Untuk biaya pengambilan sampah di setiap rumah, warga diharuskan membayar uang 10.000,00. ${ }^{35}$ Membuang

\footnotetext{
${ }^{32}$ Mochamad Widjanarko, Penulis Buku Psikologi Lingkungan Berbasis Kearifan Lokal dan Dosen Universitas Muria Kudus, Wawancara di Kampus Universitas Muria Kudus (UMK), Tanggal 16 November 2018.

33 Teguh Budi Wiyono, Bendahara Komunitas PMPH, Wawancara di Desa Colo, Tanggal 21 Oktober 2018.

${ }^{34}$ Mochamad Widjanarko, Penulis Buku Psikologi Lingkungan Berbasis Kearifan Lokal dan Dosen Universitas Muria Kudus, Wawancara di Kampus Universitas Muria Kudus (UMK), Tanggal 16 November 2018.

35 Joni Awang Ristihadi, Kepala Desa Colo, Wawancara di Desa Colo, Tanggal 15 November 2018.
} 
sampah sembarangan di hutan bisa berakibat pada kebakaran hutan, selanjutnya berdampak adanya bencana kabut asap yang akan mengganggu aktivitas manusia.

Ketiga, menjaga sumber mata air. Hutan mempunyai peranan penting dalam ketersediaan air. Hutan yang tidak gundul, akan tetap lestari. Pepohonan besar dengan akar-akarnya berfungsi sebagai penyerap air yang jatuh ke tanah. sehingga sumber mata air juga akan bertambah banyak. Air tersebut bisa dijadikan cadangan saat musim kemarau tiba. Dan hutan sebagai paru-paru dunia tidak hanya sekedar kata dan ikon.Karena kalau sudah tidak ada pohon, maka akan berakibat fatal pada sumber mata air yang bisa berujung pada kekeringan.

Menjaga sumber mata air berkaitan erat dengan menjaga tanah dari sampah-sampah. Tidak membuang sampah sembarangan adalah salah satu cara agar sumber mata air tidak tercemar. Cara lain adalah dengan mengembalikan resapan $\operatorname{air}^{36}$ dan melakukan konservasi air tanah. Hal ini tidak hanya menjadi tanggung jawab pemerintah setempat, akan tetapi semua masyarakat harus bahu membahu untuk tata kelola air, agar sumber-sumber mata air tidak lagi mengalami kekeringan saat musim kemarau.

Keempat, mengadakan patroli butan. Setiap tahun diadakan beberapa kali patroli hutan di wilayah kabupaten Kudus, Jepara dan Pati. Anggota komunitas PMPH yang hadir juga berswadaya, sebelum melakukan perjalanan patroli hutan, diadakan briefing. Perjalanan patroli dilakukan dengan jalur berbeda, baik rute saat berangkat maupun kembali. ${ }^{37}$ Para petugas patroli selalu bermalam di hutan beratapkan langit. Saat melakukan patroli, anggota juga menginventaris bagian hutan yang mengalami kerusakan dan pohon-pohon yang sudah tidak produktif. ${ }^{38}$ Patroli hutan bertujuan untuk mencegah dan membatasi kerusakan hutan atau

\footnotetext{
36 Teguh Budi Wiyono, Bendahara Komunitas PMPH, Wawancara di Desa Colo, Tanggal 21 Oktober 2018.

${ }^{37}$ Fridy Kiswantoro, Perangkat Desa KAUR Umum dan Anggota Pemuda Komunitas PMPH, wawancara di Dukuh Kombang Desa Colo, Tanggal 26 Oktober 2018.

38 Shokib Garno Sunarno, Ketua PMPH dan Juru Kunci Makam Sunan Muria, Wawancara di Desa Colo, Tanggal 20 Oktober 2018 Sabtu.
}

66 | TAJDID vol. 17, No. 1, Januari - Juni 2018 
lingkungan, kawasan hutan dan hasil hutan dari illegal logging perbuatan manusia, kebakaran, hama dan lainnya. Menjaga hutan, kawasan hutan dan lingkungannya dilakukan agar fungsi lindung, konservasi, dan produksi tercapai secara optimal dan lestari sesuai Undang-Undang perlindungan hutan.

Kelima, Melakukan reboisasi (tanam ulang). Reboisasai (tanam ulang) merupakan cara alternatif untuk melestarikan hutan. Reboisasai hutan yang telah rusak juga dapat mencegah hutan gundul. Dengan reboisasi, hutan akan tetap terjaga keberadaannya dan tetap bisa digunakan oleh manusia. Oksigen (udara) juga akan terjaga proses fotosintesisnya. ${ }^{39}$ Dengan adanya reboisasi, hutan akan senantiasa hidup. Hutan kembali hijau, asri dan lestari. Hutan lestari akan memiliki sumber mata air yang besar. Komunitas PMPH melakukan reboisasi atau tanam ulang dengan benih-benih yang bisa hidup di kawasan Pegunungan Muria. Misalnya dengan menanam pohon yang menjadi penyangga air, seperti pohon beringin, ramayana, karet dan lainnya. Para anggota terlebih dahulu melihat kondisi tanah yang hendak ditanami ulang. Jika tanah tersebut tandus akibat dari kebakaran, benih yang ditanam adalah biji pohon kaliandra.Tanaman kaliandara adalah tanaman perintis, karena mampu tumbuh menjadi pohon rintisan yang bisa menghasilkan madu lebah dan pemanggil burung-burung. Hanya saja pohon kaliandra bukan jenis tanaman penyangga air karena unsur haranya. Ketika melakukan penanaman ulang, para anggota menggunakan ketapel untuk melemparkan benih-benih tanaman yang hendak ditanam apabila tanah yang ditanam tidak bisa dijangkau. Apabila masih bisa dijangkau manusia dan bisa dilewati, maka ditanam secara langsung. ${ }^{40}$

Keenam, menjaga kawasan hutan dari kegiatan illegal logging maupun perambahan butan. Illegal logging adalah tindakan yang melanggar hukum. Merambah hutan dengan merusak tidak dibenarkan dalam agama, apalagi dalam pemerintah karena ada undang-undang yang mengatur tentang illegal logging. Di sini, pemerintah harus terlibat

${ }^{39}$ Mastur bin Mardi, Tokoh Desa Colo, Wawancara di Desa Colo, Tanggal 28 Oktober 201828.

40 Shokib Garno Sunarno, Ketua PMPH dan Juru Kunci Makam Sunan Muria, Wawancara di Desa Colo, Tanggal 20 Oktober 2018.

TAJDID Vol. 17, No. 1, Januari - Juni 2018 | 67 
dalam pelestarian hutan. Apabila ada masyarakat yang merambah hutan dengan alasan untuk bisa mencukupi kebutuhan, itu sangat disesalkan. Memberikan sanksi dengan maksud agar penebang secara liar jera terhadap apa yang sudah dilakukan, dengan harapan tidak melakukannya lagi. Menjaga kawasan hutan agar tetap asri dilakukan dengan berpatroli hutan oleh anggota $\mathrm{PMPH}^{41}$.

Ketujuh,menjaga keanekaragaman hayati di hutan Muria. Membiarkan satwa liar hidup dengan bebas di alam. Tidak memburunya dengan liar. Karena di hutan Muria masih terdapat banyak hewan langka di dalamnya. Di hutan lindung Muria, pernah ada yang meneliti dan memasang kamera trep. Dalam kamera trep itu terbukti jika masih banyak satwa langka yang hidup di hutan Muria, seperti macan dan harimau, babi hutan, kijang dan rusa, kera dan lutung, ular, dan beraneka macam burung. Di kawasan Colo masih terdapat burung elang jawa yang saat ini telah mengalami kepunahan. Elang jawa diidentikkan dengan bentuk lambang Dasar Negara Republik Indonesia. Masih banyak jenis suara burung yang memang menjadi suara khas dan hanya ditemukan di kawasan hutan Muria. Apabila satwa tersebut mengalami kepunahan, maka terpotonglah rantai makanan dan ekosistem yang telah menjadi habitat hewan. ${ }^{42}$

Kedelapan, mengembangkan tanaman produktif. Tanaman kopi dirawat sedemikian rupa dengan diolah oleh PMPH. Bahkan, saat ini kopi sudah pulih seperti zaman dahulu dengan mutu yang lebih bagus dengan adanya komunitas PMPH. ${ }^{43}$ Kopi sudah menjadi primadona untuk Muria. Oleh karenanya, hutan perlu dilestarikan. Di sela-sela tanaman kopi juga harus ada tanaman kerasnya untuk tegakan/teduhan kopinya. Kopi Muria sekarang sudah terkenal dimana-mana, dengan rasa khasnya kopi Robusta dan Arabica.

41 Shofil Fuad, Sekretaris Komunitas PMPH, Wawancara di Desa Colo, Tanggal 19 Oktober 2018.

${ }^{42}$ Kesimpulan penulis dari data yang didapatkan saat wawancara semua anggota PMPH dengan maksud yang sama dan penulis ikut langsung dalam kegiatan ekowisata yang diadakan oleh anak OSIS SMP Muhammadiyyah Kudus bersama para anggota Komunitas PMPH di Hutan Muria, Tanggal 21 Oktober 2018.

43 Mastur bin Mardi, Tokoh Desa Colo, Wawancara di Desa Colo, Tanggal 28 Oktober 2018.

68 | TAJDID vol. 17, No. 1, Januari - Juni 2018 
Bagi penikmat kopi, kopi Robusta adalah kopi paling enak di wilayah Muria dan banyak dibudayakan oleh petani. Selain kopi, PMPH juga menanam buah parijoto. Parijoto memang bukan endemik Muria, karena tanaman parijoto mampu hidup di pegunungan dengan kelembaban tinggi. Parijoto adalah tanaman yang tidak tergantung pada musim, karena parijoto bisa kapan saja berbuah. Di kawasan Muria, di pegunungan atas memang banyak ditumbuhi kopi dan parijoto. Kopi harus ada perlakuan spesial, berbeda dengan parijoto. Masyarakat Muria, ada yang sudah dari buah parijoto menjadi sirup parijoto. ${ }^{44}$

Kesembilan, mengembangkan daerah ekowisata. PMPH sudah menggalakkan ekowisata, kendati belum dibuka secara besarbesaran. Adanya paket ekowisata, memberikan edukasi tentang tanaman kopi. Setiap ada kegiatan, paket yang ditawarkan adalah tentang edukasi menjaga kelestarian lingkungan Hutan Muria. Hal tersebut sesuai dengan visi PMPH untuk kampanye tentang konservasi alam.

Pelestarian lingkungan hidup di hutan Muria berdampak sangat signifikan bagi Masyarakat ${ }^{45}$. Dahulu saat marak-maraknya illegal logging (perambahan hutan), suhu udara di kawasan pegunungan Muria ini sangat panas, lambat laun di Colo sudah jauh lebih adem dan sejuk dibanding tahun 1998-2000. ${ }^{46}$ Kebutuhan oksigen dapat terpenuhi dengan adanya proses fotosintesis dari tumbuhan yang berfungsi sebagai penyerap karbondioksida. Mengurangi polusi dan pencemaran udara menjadi cara alternatif untuk menghasilkan udara bersih bagi manusia. Bencana longsor maupun banjir juga dapat diminimalisir dan dicegah dengan adanya upaya pelestarian lingkungan hutan.

Komunitas PMPH berharap dengan digalakkannya pelestarikan hutan, masyarakat dapat mengambil manfaat hutan tanpa harus merusaknya dengan penebangan hutan ataupun

\footnotetext{
44 Sutrimo, Petani Kopi dan Buah Parijoto Terbesar di Wilayah Colo, Wawancara di Dukuh Pandak, Tanggal 15 November 2018.

45 Kesimpulan penulis dari data yang didapatkan saat wawancara semua anggota PMPH dengan maksud yang sama.

46 Shofil Fuad, Sekretaris Komunitas PMPH, wawancara di Desa Colo, Tanggal 19 Oktober 2018.
}

TAJDID Vol. 17, No. 1, Januari - Juni 2018 | 69 
perambahan hutan. Biarlah hutan itu seperti itu, masih rimba, masih asri dengan beragam tanaman kopi, parijoto, alpukat, dan apotik hidup. Secara ekonomi, PMPH juga mampu menggalakkan ekowisata sebagai wahana belajar alam dan pelestarian hutan. Memberikan edukasi tentang alam dan tentang pepohonan, satwasatwa yang ada dan harus dilindungi keberadaannya.

Pelestarian alam dan lingkungan hidup hutan Muria berdampak positif bagi sumber mata air, baik yang digunakan oleh warga Desa Colo dan sekitarnya, maupun warga di bawah Desa Colo yang meliputi tiga kabupaten. Pada era reformasi, saat maraknya perambahan hutan, sumber mata air jumlahnya sangat terbatas. Upaya pelestarian alam dengan cara menanam pohon yang bisa menjadi penyangga air, mampu menjaga dan menambah volume sumber mata air sehingga semakin berlimpah ruah.

Al-Qur'an telah banyak ayat-ayat yang menjelaskan tentang konsep pelestarian lingkungan hidup. Adanya konsep pertama, kata al-islab yaitu memperbaiki setelah ada kerusakan. Kedua, kata alihsan yaitu memelihara dan berbuat kebaikan. Konsep ketiga, kata taskbir dari kata sakhara yang artinya menundukkan. Konsep keempat, kata ta'mir yang artinya memakmurkan ${ }^{47}$. Upaya yang dilakukan oleh kelompok PMPH sejalan dengan sitiran al-Qur'an untuk peduli dengan alam sekitar, baik aktifitas islah, ibsan, taskhir maupun ta'mir. Konsep al-Ihsan terdapat dalam Q.S. Al-Qashash (28): 77 ;

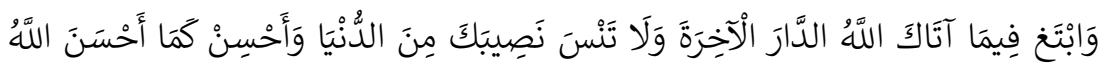

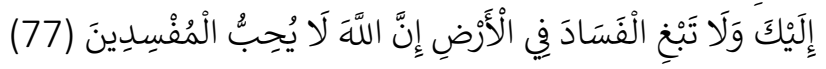

Terjemah:

"Dan carilah pada apa yang telah dianugerabkan Allah kepadamu (kebahagiaan) negeri akhirat, dan janganlah kamu melupakan bagianmu dari (kenikmatan) duniawi dan berbuat baiklah (kepada orang lain) sebagaimana Allah telah berbuat baik, kepadamu, dan janganlah kamu berbuat kerusakan di (muka)bumi. Sesunggubnya allah tidak menyukai orang-orang yang berbuat kerusakan".

47 Abdurrahman, Al-Qur'an Dan Isu-Isu Kontemporer (Yogyakarta: eLSAQ Press, 2011), 196.

70 | TAJDID vol. 17, No. 1, Januari - Juni 2018 
Konsep ibsan dalam ayat tersebut memiliki dua makna, pertama, memelihara dan menjaga dengan sempurna. Kedua, adalah menyayangi, memperhatikan, merawat serta menghormati.

Kenikmatan dunia dirasakan bagi manusia yang merasakan hal positif dari hasil penjagaan alam lingkungan. Selain itu, dengan menjaga lingkungan dan membuat orang lain merasakan kebahagiaan berarti kita telah menorehkan suatu pahala. Penjelasan ini sama dengan keyakinan anggota PMPH bahwa melestarikan alam, berbuat baik dengan alam dan lingkungan sama dengan beramal untuk masa depan.

Upaya-upaya yang telah dipaparkan oleh penulis dari hasil wawancara dengan anggota PMPH memberikan bukti, bahwa mengembalikan kesadaran masyarakat menjadi sangat penting di saat para manusia sudah kehilangan akhlak dan moralnya. Secara ekologis kaidah penanggulangan kerusakan fisik lingkungan (penyakit) melalui 3 tahapan, pertama, dengan cara menjaga kesehatan fisik lingkungan, kedua, menghindari perusakan fisik lingkungan dan ketiga, dengan cara mengisolasi dan apabila diperlukan harus mengamputasi kerusakan fisik lingkungan. Ketiga-tiganya dapat dianalogkan secara urut untuk menciptakan keseimbangan dan homeostasi ekologi maupun lingkungan hidup yang dalam kondisi suksesi sekunder dan suksesi primer ${ }^{48}$. Adanya upaya patroli hutan dan tindakan tegas bagi pelaku perambah hutan, mengindikasikan upaya mengindari dan menghentikan perbuatan fasad di muka bumi yang memberikan dampak luar biasa dengan adanya beragam bencana yang justeru menjadi bumerang dan merugikan bagi manusia (Q.S. Ar-Ruum (30): 14).

Ayat ini diselaraskan dengan ayat konsep pelestarian lingkungan dalam al-Qur'an yakni konsep al-islab yang artinya memperbaiki kembali jika ada kerusakan, mendamaikan dan menjadikan sesuatu berguna dan bermanfaat (Q.S. Al-A'raf (7): 56;

48 Achmad Cholil Zuhdi, "Krisis Lingkungan Hidup Dalam Prespektif AlQur'an," Mutawatir: Jurnal Keilmuan Tafsir Hadis 2, no. 2 (2012): 158, http://mutawatir.uinsby.ac.id/index.php/Mutawatir/article/view/25/24.

TAJDID Vol. 17, No. 1, Januari - Juni 2018 | 71 


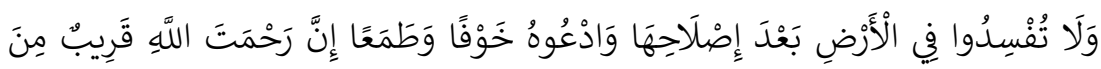

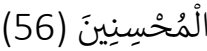

"Dan janganlah kamu berbuat kerusakan di muka bumi, sesudah (Allah) memperbaikinya dan berdoalab kepadaNya dengan rasa takut (tidak akan diterima) dan harapan (akan dikabulkan). Sesunggubnya rahmat Allah amat dekatkepada orang-orang yang berbuat baik.".

Kata islah yang dijelaskan adalah Allah yang membuat kemaslahatan. Maka apabila telah diperbaiki dari kerusakan, maka jangan membuat kerusakan lagi apabila tidak sanggup untuk memperbaikinya. Hal ini sangat terkait erat dengan apa yang telah dikampanyekan oleh kelompok PMPH. Tugas manusia tidak hanya mengolahnya tetapi mempunyai kewajiban memakmurkannya dalam arti menjaganya. Selaras dengan konsep ta'mir yang artinya adalah memakmurkan. Manusia diciptakan oleh Allah sebagai khalifah di bumi, agar kelak mampu memakmurkan bumi.

Konservasi alam merupakan amanah bagi manusia untuk memelihara kehidupan dengan segenap sistemnya dan merupakan salah satu dari tujuan syariah (maqäsid al-sharíah), bahkan tujuan tertinggi. Konservasi yang dilakukan melalui pelestarian, perlindungan, pemanfaatan secara lestari, rehabilitasi, dan peningkatan mutu lingkungan pada dasarnya untuk menjamin kemaslahatan manusia beserta makhluk hidup lainnya dalam jangka panjang dan berkesinambungan ${ }^{49}$.

Dalam prespektif Islam, kehidupan alam berjalan berlandaskan pada prinsip keselarasan dan keseimbangan. Konsep lingkungan diperkenalkan oleh al- Qur'an dengan beragam bentuk dan model kata, yakni kata al-'alamin, al-sama', al-ardh, dan al-bi 'ah . Adanya beberapa ayat-ayat yang menjelaskan masalah ekologi, dapat dijadikan sebagai rumusan "Agama Hijau". "Agama Hijau"(greendeen) adalah agama yang menuntut manusia untuk menerapkan Islam seraya menegaskan hubungan integral antara

49 Dede Rodin, "Al Quran Dan Konservasi Lingkungan: Telaah Ayat-Ayat Ekologis," Al-Tabrir 17, no. 2 (2017): 391-410, http://jurnal.iainponorogo.ac.id/index.php/tahrir/article/view/1035.

72 | TAJDID vol. 17, No. 1, Januari - Juni 2018 
keimanan dan lingkungan (seluruh semesta). "Agama Hijau" (greendeen) dibangun atas enam prinsip yang saling berkaitan. Pertama, prinsip tauhid, yakni pemahaman memahami kesatuan Tuhan dan ciptaan-Nya (lingkungan); kedua, prinsip bahwa alam dan lingkungan adalah bagian dari tanda-tanda (ayat) Allah di alam semesta; ketiga, prinsip kedudukan manusia sebagai wakil Allah di bumi (khalifatulläh fi al-ard ); keempat, prinsip amanah, dimana dalam kapasitasnya sebagai khalifah manusia diberi amanah untuk memanfaatkan alam ini dengan sebaik-baiknya dan penuh tanggungjawab; kelima, prinsip keadilan ('ad), dan keenam, prinsip keselarasan dan keseimbangan (al-tawäzun, equilibrium), sehingga rusaknya lingkungan karena manusia mengabaikan prinsip keseimbangan alam ${ }^{51}$.

Dalam taksonomi ajaran Islam, sejatinya akhlak atau moral merupakan dimensi ketiga dari ajaran Islam sebagai materi dakwah setelah aqidah dan syari'ah. Akhlak, menyangkut maasalahmasalah kehidupan yang bekaitan dengan ketentuan-ketenetuan dan ukuran-ukuran baik dan buruk atau benar salahnya suatu perbuatan. Perbuatan itu dapat berupa perbuatan lahir, dapat juga berupa perbuatan batin. Akhlak berkenaan dengan bagaimana seharusnya orang bertindak sehingga ia dapat mengukur dan diukur moralitasnya. Ketika seorang individu tidak dapat menghargai lingkungan hidupnya, malahan merusak dan mengeksploitasinya dengan tidak melakukan recovery, posisinya sama dengan menentang ukuran-Nya berupa keteraturan ekosistem di lingkungan sekitar. Oleh karena itu, pemeliharaan lingkungan hidup merupakan penentuan keseimbangan alam. Dalam konteks ini, akhlak dapat diartikan sebagai kesalehan ekologis, dan dalam perspektif dakwah, mereka yang sadar bahwa

\footnotetext{
${ }^{50}$ Ahmad Suhendra, "Menelisik Ekologis Dalam Al-Qur'an," ESENSLA 14, no. 1 (2013): 79, http://mutawatir.uinsby.ac.id/index.php/Mutawatir/article/view/25/24.

51 Rodin, "Al Quran Dan Konservasi Lingkungan: Telaah Ayat-Ayat Ekologis," 408.
} 
alam mesti dihargai karena amanat dari-Nya, memiliki paradigma dakwah lingkungan berbasis Al-Qur'an ${ }^{52}$.

Eko-teologi melihat konservasi alam bukan hanya sebagai cara untuk mempertahankan peradaban, tetapi juga sebagai alat untuk menyembuhkan akar- akar krisis ekologi yang tidak lagi terletak pada teknologi tapi pada keimanan dan struktur nilai manusia yang mengendalikan teknologi. Eko-sufisme menegaskan bahwa kesadaran spiritual yang diperoleh dengan cara memaknai interaksi antara sistem wujud terutama pada lingkungan sekitar. Lingkungan merupakan media atau sarana untuk dzikir dan sampai (wushûl) kepada Allah. Alam adalah sumber kearifan, sehingga harus diberlakukan dengan bijaksana. Merusak alam sama dengan merusak kehidupan sekaligus merusak sarana ma'rifah. Manusia mengemban tiga amanah dari Allah dalam berinteraksi dengan alam serta lingkungan hidup, al-intifâ' al-i'tibâr, dan al-ishlâh ${ }^{53}$.

\section{Kesimpulan}

Komunitas Paguyuban Masyarakat Peduli Hutan (PMPH) di desa Colo kecamatan Dawe Kabupaten Kudus telah melakukan aktifitas-aktifitas/perilaku-perilaku (living Qur'an) yang sejatinya merupakan nilai-nilai al-Qur'an tentang tugas manusia untuk menjaga dan melestarikan alam semesta agar dapat membawa manfaat dan maslahah untuk sesama. Konservasi alam bagi komunitas PMPH dimaknai sebagai amanah yang bersifat niscaya, sebagai manifestasi rasa syukur atas karunia Allah yang telah menghamparkan segala kebutuhan manusia di alam raya, terutama hutan. Konservasi alam juga memiliki status sebagai manifestasi kesalehan, keimanan dan ibadah kepada Allah swt. Kepedulian akan lingkungan hutan berarti menunjukkan sikap peduli tidak hanya kepada alam, namun juga wujud kepedulian terhadap kelestarian generasi masa mendatang. Akhirnya, komunitas PMPH meyakini bahwa sikap peduli dan aksi untuk kelestarian hutan

\footnotetext{
52 Asep Muhyiddin, “Dakwah Lingkungan Prespektif Al-Qur'an,” Jurnal Ilmu $\begin{array}{lllll}\text { Dakwah } & 4, & & \end{array}$ http://journal.uinsgd.ac.id/index.php/idajhs/article/view/423/436.

53 Abd. Aziz, "Konservasi Alam Dalam Perspektif Etika Islam; Tantangan Dan Tuntutan Globalisasi," Akademika 19, no. 2 (2014): 320, http://ejournal.metrouniv.ac.id/index.php/akademika/article/view/417/431.
} 
adalah amal jariyah yang pahalanya akan terus mengalir. Wallabu a'lamu bi al-sawab

\section{Daftar Pustaka}

Abdurrahman. Al-Qur'an Dan Isu-Isu Kontemporer. Yogyakarta: eLSAQ Press, 2011.

Aziz, Abd. "Konservasi Alam Dalam Perspektif Etika Islam; Tantangan Dan Tuntutan Globalisasi." Akademika 19, no. 2 (2014).

http://ejournal.metrouniv.ac.id/index.php/akademika/article/view/4 $17 / 431$.

"Kategori Daerah Rawan Bencana, Pemkab Dan Polres Kudus Gelar Apel Siaga Bencana." Kategori daerah rawan bencana, pemkab dan Polres Kudus gelar apel siaga bencana, 2018. https://elshinta.com/news/128958/0000/00/00/kategoridaerah-rawan-bencana-pemkab-dan-polres-kudus-gelar-apelsiaga-bencana.

Khafidhoh. "Teologi Bencana Dalam Perspektif M. Quraish Shihab." ESENSIA 14, no. 1 (2013). http://ejournal.uinsuka.ac.id/ushuluddin/esensia/article/view/141-03/693.

Muhtador, Moh. "Pemaknaan Ayat Al-Quran Dalam Mujahadah: Studi Living Qur' an Di PP Al-Munawwir Krapyak Komplek Al- Kandiyas." Jurnal Penelitian 8, no. 1 (2014): 93-112. journal.stainkudus.ac.id/index.php/jurnalPenelitian/article/d ownload/1343/1187.

Muhyiddin, Asep. "Dakwah Lingkungan Prespektif Al-Qur'an." Jurnal Ilmu Dakwah 4, no. 15 (2010): 809-25. http://journal.uinsgd.ac.id/index.php/idajhs/article/view/42 $3 / 436$.

Mumpuni, Kistantia Elok, Herawati Susilo, and Fatchur Rohman. "Peran Masyarakat Dalam Upaya Konservasi The Role of Society Toward Concervation." In Seminar Nasional XII Pendidikan Biologi FKIP UNS 2015, 779-82. LIPI, 2015. http://jmb.lipi.go.id/index.php/jmb/article/view/344/294.

TAJDID Vol. 17, No. 1, Januari - Juni 2018 | 75 
Mustaqim, Abdul. "Metode Penelitian Living Qur'an Model Penelitian Kualitatif.” In Metodologi Penelitian Living Qur'an Dan Hadis, 1st ed., 65-80. Yogyakarta: Teras, 2007.

Putra, Heddy Shri Ahimsa. "The Living Al-Qur'an: Beberapa Perspektif Antropologi." Jurnal Penelitian Sosial Keagamaan 20, no. 1 (2012): $235-60$. http://www.journal.walisongo.ac.id/index.php/walisongo/ar ticle/view/198/179.

Rodin, Dede. "Al Quran Dan Konservasi Lingkungan: Telaah Ayat-Ayat Ekologis." Al-Tahrir 17, no. 2 (2017): 391-410. http://jurnal.iainponorogo.ac.id/index.php/tahrir/article/vie $\mathrm{w} / 1035$.

Suhendra, Ahmad. "Menelisik Ekologis Dalam Al-Qur'an." ESENSIA 14, no. 1 (2013): 61-82. http://mutawatir.uinsby.ac.id/index.php/Mutawatir/article/ view/25/24.

"Waspada Bencana Banjir, Pemkab Kudus Bentuk Emergency Center Di Bawah BPBD - Tribun Jateng," 2018. http://jateng.tribunnews.com/2018/11/16/waspadabencana-banjir-pemkab-kudus-bentuk-emergency-center-dibawah-bpbd.

Wibowo, Hendro Ari, Wasino \& Dewi Lisnoor Setyowati. "Kearifan Lokal Dalam Menjaga Lingkungan Hidup (Studi Kasus Masyarakat Di Desa Colo Kecamatan Dawe Kabupaten Kudus)." Journal of Educational Social Studies 1, no. 1 (2012): 25-30. https://journal.unnes.ac.id/sju/index.php/jess/article/view/ $79 / 71$.

Widjatnarko, Mochamad. PsikologiLingkungan. Kudus: Badan Penerbit Universitas Muria Kudus, 2014.

Zuhdi, Achmad Cholil. "Krisis Lingkungan Hidup Dalam Prespektif Al-Qur'an.” Mutawatir: Jurnal Keilmuan Tafsir Hadis 2, no. 2 (2012): 140-62.

76 | TAJDID vol. 17, No. 1, Januari - Juni 2018 